\title{
Peptidases are affected differently in neocortical regions of brains from patients with Alzheimer's Disease
}

Citation for published version (APA):

Terwel, D., Markerink, M., \& Jolles, J. (1992). Peptidases are affected differently in neocortical regions of brains from patients with Alzheimer's Disease. Dementia and Geriatric Cognitive Disorders, 3, 108-113. https://doi.org/10.1159/000107003

Document status and date:

Published: 01/01/1992

DOI:

10.1159/000107003

Document Version:

Publisher's PDF, also known as Version of record

Please check the document version of this publication:

- A submitted manuscript is the version of the article upon submission and before peer-review. There can be important differences between the submitted version and the official published version of record.

People interested in the research are advised to contact the author for the final version of the publication, or visit the DOI to the publisher's website.

- The final author version and the galley proof are versions of the publication after peer review.

- The final published version features the final layout of the paper including the volume, issue and page numbers.

Link to publication

\footnotetext{
General rights rights.

- You may freely distribute the URL identifying the publication in the public portal. please follow below link for the End User Agreement:

www.umlib.nl/taverne-license

Take down policy

If you believe that this document breaches copyright please contact us at:

repository@maastrichtuniversity.nl

providing details and we will investigate your claim.
}

Copyright and moral rights for the publications made accessible in the public portal are retained by the authors and/or other copyright owners and it is a condition of accessing publications that users recognise and abide by the legal requirements associated with these

- Users may download and print one copy of any publication from the public portal for the purpose of private study or research.

- You may not further distribute the material or use it for any profit-making activity or commercial gain

If the publication is distributed under the terms of Article $25 \mathrm{fa}$ of the Dutch Copyright Act, indicated by the "Taverne" license above, 


\section{Dirk Terwel \\ Marjanne Markerink Jellemer Jolles}

Department of Neuropsychology and Psychobiology, University of Limburg, Maastricht, The Netherlands

\section{Peptidases Are Affected Differently in Neocortical Regions of Brains from Patients with Alzheimer's Disease}

\section{Key Words}

Alzheimer's disease

Prolylendopeptidase

Aminopeptidase

Frontal cortex

\begin{abstract}
Although it is recognized that changes in protease activities may be involved in the etiology of pathological changes in the human brain, there have been few studies on normal and pathological protein catabolism. In the present study the activities of major cortical aminopeptidase and prolylendopeptidase were determined in frontal and medial temporal cortical samples of brains from patients with Alzheimer's disease (AD) and control patients matched for age. Prolylendopeptidase activity was reduced by $45-50 \%$ in the frontal and medial temporal cortex of AD patients as compared with controls, whereas major aminopeptidase activity was unaltered. The possibility that the changes in peptidase activities in AD are age-dependent was studied in postmortem neocortical samples from $18 \mathrm{AD}$ patients who had died between 55 and 90 years of age. Prolylendopeptidase activity was lower in patients who died at a relatively early age than in patients who died at a relatively old age. This underscores the notion that, with respect to age, there may be heterogeneity in neurochemical changes in $\mathrm{AD}$.
\end{abstract}

\section{Introduction}

Alzheimer's disease (AD) is the most prevalent neurodegenerative disorder causing dementia and affects $5 \%$ of the population over 65 years of age [1]. This disease is characterized by large numbers of neuritic plaques and neurofibrillary tangles, and is associated with many biochemical alterations, such as reduced activities of choline acetyltransferase and dopamine- $\beta$-hydroxylase [2-5], altered phosphorylation of cytoskeletal proteins [6], and abnormal protein processing leading to deposition of $\beta$ amyloid peptide [7]. How these biochemical alterations relate to each other and to the cause and pathogenesis of
$\mathrm{AD}$ is not yet understood. The observation that the formation of neuritic plaques results from abnormal protein deposition prompted investigators to look for abnormalities in protein catabolism in $\mathrm{AD}$. For instance, serine proteases [8] (various complement factors), serine protease inhibitors [9], and calpain [10] have been identified as components of neuritic plaques. Ubiquitin, a small protein involved in energy-dependent proteolysis, is present in neurofibrillary tangles [11]. Several studies on peptidase activities in AD have been carried out. Mantle et al. [12] did not find changes in major aminopeptidase activity in neocortical samples from $A D$ patients. Likewise, Kawashima et al. [13] and Nilsson et al. [14] failed to find
Accepted:

January 13, 1992
Dirk Terwel, MD
Department of Neuropsychology and Psychobiology

University of Limburg. PO Box 616

NL-6200 MD Maastricht (The Netherlands) (c) 1992 S. Karger AG, Basel 1013-7424/92/0032-0108 $\$ 2.75 / 0$ 
Table 1. Patient information

\begin{tabular}{|c|c|c|c|c|}
\hline Cases & $\begin{array}{l}\text { Age, } \\
\text { sex }\end{array}$ & $\begin{array}{l}\text { Brain } \\
\text { weight, } g\end{array}$ & $\begin{array}{l}\text { Postmortem } \\
\text { delay, min }\end{array}$ & Cause of death \\
\hline \multicolumn{5}{|c|}{ Controls } \\
\hline 1 & $60 \mathrm{M}$ & 1,350 & 360 & septic shock following aorta valve implantation \\
\hline 2 & $65 \mathrm{M}$ & 1,310 & 315 & heart failure \\
\hline 3 & $66 \mathrm{~F}$ & 1,100 & 375 & postoperative heart failure \\
\hline 4 & $71 \mathrm{~F}$ & 1,240 & 305 & sepsis and cardiogenic shock \\
\hline 5 & $73 \mathrm{M}$ & 1,340 & 255 & cerebral infarct \\
\hline \multicolumn{5}{|l|}{ AD } \\
\hline 1 & $55 \mathrm{M}$ & 1,020 & 180 & pneumonia, cachexia and dehydration \\
\hline 2 & $64 \mathrm{M}$ & 1,210 & 330 & collum fracture (died after operation) \\
\hline 3 & $65 \mathrm{M}$ & 1,360 & 240 & pulmonary embolism, dehydration \\
\hline 4 & $68 \mathrm{~F}$ & 895 & 345 & bronchopneumonia \\
\hline 5 & $70 \mathrm{M}$ & 1,075 & 270 & cachexia \\
\hline 6 & $72 \mathrm{M}$ & 1,040 & 285 & pneumonia and cachexia \\
\hline 7 & $79 \mathrm{~F}$ & 1,010 & 245 & bronchopneumonia and cachexia \\
\hline 8 & $81 \mathrm{~F}$ & 910 & 225 & pneumonia and heart disease \\
\hline 9 & $84 \mathrm{~F}$ & 920 & 205 & pneumonia \\
\hline 10 & $88 \mathrm{~F}$ & 1,070 & 225 & pneumonia \\
\hline 11 & $81 \mathrm{~F}$ & 1,130 & 330 & suffocation \\
\hline 12 & $85 \mathrm{~F}$ & 1,020 & 135 & intestinal bleeding \\
\hline 13 & $87 \mathrm{~F}$ & 950 & 235 & apnea following postoperative irreversible hypotension \\
\hline 14 & $89 \mathrm{~F}$ & 940 & 250 & pneumonia \\
\hline 15 & $88 \mathrm{~F}$ & 960 & 225 & lung infection \\
\hline 16 & $89 \mathrm{~F}$ & 1,050 & 200 & unknown \\
\hline 17 & $90 \mathrm{~F}$ & 840 & 230 & cachexia and dehydration \\
\hline 18 & $90 \mathrm{~F}$ & 1,000 & 270 & acute myocard infarct, massive pulmonary embolism \\
\hline
\end{tabular}

changes in calpain activity in AD brains. Aoyagi et al. [15] measured aminopeptidase, dipeptidylpeptidase, cathep$\sin \mathrm{B}$ and serine protease activities in occipital cortex from AD patients and observed decreased kallikrein activity and increased prolylendopeptidase activity. The fact that only these two proteases were affected in $\mathrm{AD}$ may be related to the age distribution of the patients examined, since it has been observed that neurochemical markers of $\mathrm{AD}$ are influenced by age [16]. It is thus important to consider age when studying neurochemical changes in $\mathrm{AD}$. Major aminopeptidase is the most active aminopeptidase and prolylendopeptidase is the most active serine protease of brain tissue $[17,18]$. Their ubiquitous nature suggests that they serve a fundamental role in protein turnover. So far these enzymes were studied in relatively old $\mathrm{AD}$ patients only $[12,15]$. Therefore it was considered important to determine these enzyme activities in $\mathrm{AD}$ patients with respect to age. Firstly, major aminopeptidase and prolylendopeptidase activities were determined in neocortical autopsy samples from relatively young $\mathrm{AD}$ and control patients matched for age and post- mortem delay. Secondly, these enzyme activities were determined in tissue from $A D$ patients who died between 55 and 90 years of age.

\section{Materials and Methods}

Brain tissues were obtained from the Netherlands Brain Bank. Eighteen patients ( 5 male, 13 female; age range $55-90$ years) were selected that had been clinically diagnosed as probable Alzheimer cases according to the NINCDS-ADRDA criteria [19] (for patient information see table 1). They had a score of 6-7 on the Global Deterioration Scale of severity of dementia [20]. The clinical diagnosis of AD was verified by postmortem neuropathological examination of formalin-fixed specimens. Five $A D$ patients were selected for the first experiment [ 4 male, 1 female; mean age (SD) 68 (3); postmortem delay (SD) 294 (43) min; No. 2-6, table 1]. Five patients with no evidence of dementia and no history of other neurological or psychiatric disorders were selected as normal controls [ 3 male, 2 female; mean age (SD) 67 (5); postmortem delay (SD) 322 (48) min; No. 1-5, table 1]. Tissue blocks of about $1 \mathrm{~g}$ fresh weight were excised from the frontal superior gyrus and the medial temporal gyrus. The leptomeninges were removed and the samples were rapidly frozen in liquid nitrogen. The frozen samples were stored at $-80^{\circ} \mathrm{C}$ until use. Brain 

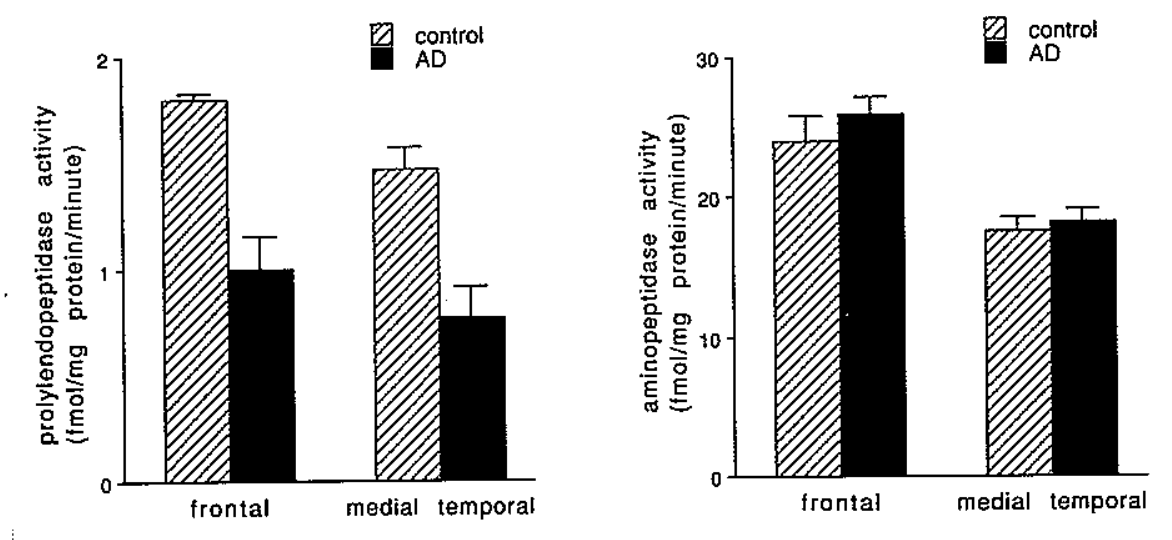

Fig. 1. Prolylendopeptidase (A) and major aminopeptidase (B) activities in medial temporal and frontal cortex of AD and control patients matched for age. Each group consisted of 5 patients.

tissue samples were homogenized in 9 volumes $0.32 \mathrm{M}$ sucrose, $1 \mathrm{~m} M$ EGTA, $50 \mathrm{~m} M$ Tris, pH 7.4, in a Potter-Elvehjem Teflon-glass homogenizer (12 up-and-down strokes, $700 \mathrm{rpm}, 0.25 \mathrm{~mm}$ clearance). The homogenates were centrifuged at $100,000 \mathrm{~g}$ for $60 \mathrm{~min}$ and the resulting membrane-free fraction was frozen in liquid nitrogen and stored at $-80^{\circ} \mathrm{C}$ until determination of peptidase activities.

Assay for the Determination of Major Aminopeptidase Activity

Aminopeptidase activity was measured with a modification of a previously reported assay [21]. Vasopressin iodinated in the Tyr ${ }^{2}$ position was used as peptide substrate (Amersham, UK). Two incubations were carried out, either in the presence of $32 \mu \mathrm{M}$ puromycine or in the absence of the inhibitor. The difference between the release of Tyr in these two incubations was used as an index of puromycin sensitive (major) aminopeptidase activity. Iodinated VP was incubated with $2.5 \mu \mathrm{g}$ cytosolic protein for $2.5 \mathrm{~min}$ in $100 \mu \mathrm{l}$ of a buffer consisting of $50 \mathrm{mM}$ Tris- $\mathrm{HCl}$ (pH 7.4), $1 \mathrm{mg}$ human serum albu$\mathrm{min} / \mathrm{ml}$ and $1 \mathrm{~m} M$ dithiotreitol. Conditions were chosen such that less than $20 \%$ of the substrate was converted. The reaction was stopped by the addition of $0.9 \mathrm{ml} 0.1 \mathrm{MNaOH}$. lodinated Tyr was separated from the substrate by the addition of $50 \mathrm{mg}$ Amberlite XAD-2 (BDH, Pool, UK) prewetted with $50 \mu$ ethanol. The tubes were kept in a rotary tumbler (Luckham, Burgess Hill, UK) for 30 min to allow VP to bind to the beads. Beads were spun down at low speed and the Tyr containing supernatants were pipetted off.

\section{Assay for the Determination of Prolylendopeptidase Activity}

The prolylendopeptidase assay was based on the method of Davison et al. [22]. Iodinated VP was used as a substrate. Davison et al. determined $\mathrm{N}$-terminal conversion of the peptide. In the present study, C-terminal conversion of the peptide was assessed as the reduced binding of radioactivity to excess $\mathrm{C}$-terminus recognizing antibody. The antibody has been characterized previously [23]. Iodinated VP (10 $\mathrm{p} M)$ was incubated with $12.5 \mu \mathrm{g}$ of cytosolic protein for $5 \mathrm{~min}$ in $100 \mu \mathrm{l}$ of a buffer consisting of $50 \mathrm{mM}$ Tris- $\mathrm{HCl}(\mathrm{pH}$ 7.4), $1 \mathrm{mg} \mathrm{HSA} / \mathrm{ml}$ and $1 \mathrm{~m} M$ 1,10-phenanthroline. 1,10-Phenanthroline was present during the incubation to inhibit aminopeptidase activity. Conditions were chosen such that less than $20 \%$ of the substrate was converted. The reaction was stopped by addition of $0.4 \mathrm{ml}$ $1 \mathrm{M}$ acetic acid and boiling for $5 \mathrm{~min}$. Flocculent material was removed by centrifugation $\left(50 \times 10^{3} \mathrm{~g}, 30 \mathrm{~min}\right)$. The supernatants were evaporated under vacuum (Speed Vac Concentrator). The freeze-dried residues were dissolved in $200 \mu \mathrm{l}$ of a Veronal/HSA buffer. Diluted anti-VP antiserum $(1: 1,000 ; 25 \mu \mathrm{l})$ was added to $50-\mu \mathrm{l}$ aliquots. After $72 \mathrm{~h}$ of incubation bound and free radioactivity were separated by the addition of $100 \mu$ of a suspension of dextranFicoll-coated charcoal [24]. Charcoal was spun down and the supernatant was removed by suction. Charcoal pellets were counted in a well-type $\gamma$-counter.

\section{Results}

Prolylendopeptidase and major aminopeptidase activities were determined in autopsy samples of the frontal superior gyrus of $5 \mathrm{AD}$ patients and control subjects matched for age and postmortem delay. Total aminopeptidase activity consisted of puromycin-sensitive aminopeptidase activity only, that is puromycin-insensitive activity was not detected. Prolylendopeptidase activity was reduced by 44 and $48 \%$ in the frontal and medial temporal cortex of the $5 \mathrm{AD}$ patients as compared with the 5 control patients matched for age ( $p$ values $<0.01$, fig. 1 a). Aminopeptidase activity was not affected in the $5 \mathrm{AD}$ patients ( $p$ values $>0.05$, fig. $1 b$ ).

Peptidase activities were determined in medial temporal cortex samples of $18 \mathrm{AD}$ patients who had died between 55 and 90 years of age. Using a split half design, we tested whether there was an age-related difference in $\mathrm{AD}$ patients with respect to peptidase activities. The older AD 
A

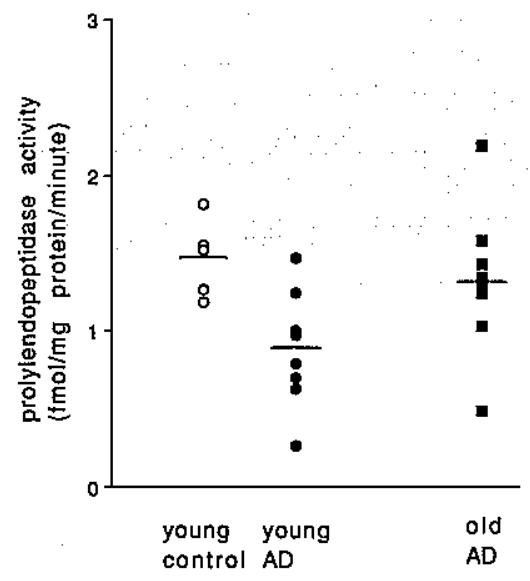

Fig. 2. Prolylendopeptidase (A) and aminopeptidase (B) activities in medial temporal cortex of control patients (O), AD patients younger than 84 years $(\bullet)$ and AD patients older than 84 years $(\square)$.

patients ( $>84$ years) had a significantly higher prolylendopeptidase activity than the younger ones $(<84$ years) $(\mathrm{p}<0.05$, fig. $2 \mathrm{a})$. The older AD patients did not differ from the 5 control patients ( $p>0.05$ ), but the younger $\mathrm{AD}$ patients did $(\mathrm{p}<0.01$, fig. $2 \mathrm{a})$. Comparisons with older control patients were not possible because material from older control patients was not available. Aminopeptidase activity was unrelated to age in $A D$ patients $(p>$ 0.05 , fig. $2 b$ ).

To investigate whether the lower prolylendopeptidase activity was caused by either the presence of an endogenous inhibitor or the absence of a cofactor in cytosolic fractions of neocortical tissue from AD patients, cytosolic fractions prepared from $\mathrm{AD}$ material were combined with cytosolic fractions prepared from control material. Combination of cytosolic fractions did not result in a decrease in the sum of activities ( $p>0.05$, fig. 3 ). Heat-denatured cytosolic fractions of $\mathrm{AD}$ patients did not affect the prolylendopeptidase activity of cytosolic fractions of controls or vice versa ( $\mathrm{p}$ values $>0.05$, fig. 3 ).

\section{Discussion}

In the present study two peptidase activities were measured in postmortem brain samples of patients with $\mathrm{AD}$ and of control patients. Prolylendopeptidase was determined radioimmmunochemically and aminopeptidase radiometrically with vasopressin iodinated in the $\mathrm{Tyr}^{2}$ position. We used these methods on the basis of our experience with the measurement of the conversion of vaso-

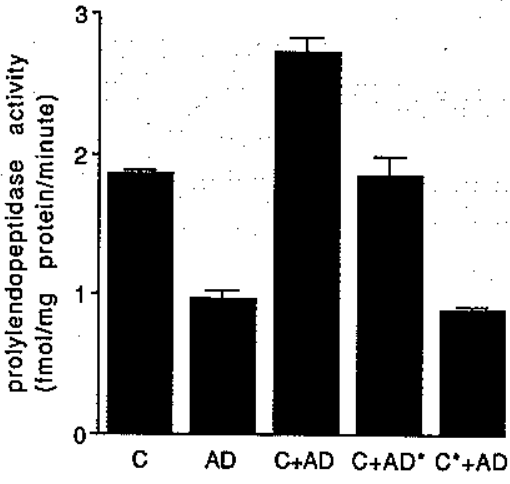

Fig. 3. Prolylendopeptidase activity in cytosolic fractions of frontal cortex of control patients and $A D$ patients, combined fractions $(C+A D)$, combined control and heat-denatured $\mathrm{AD}$ fractions ( $\left.\mathrm{C}+\mathrm{AD}^{*}\right)$ and combined heat-denatured control and $\mathrm{Alz}$ heimer's disease fractions $\left(C^{*}+A D\right)$. Heat denaturation was achieved by heating at $65^{\circ} \mathrm{C}$ for $30 \mathrm{~min}$.

pressin by membrane and cytosolic fractions and with the radioimmunoassay of vasopressin $[21,24,25]$. Since vasopressin is not present in brain cortex, this study is not of relevance to the in vivo conversion of vasopressin. It has been shown previoulsy that vasopressin is converted by purified major cytosolic aminopeptidase [17] and prolylendopeptidase [18]. In addition, vasopressin is converted by both $\mathrm{N}$ - and C-terminal degrading enzymes when incubated with a cytosolic fraction [21]. When assessing prolylendopeptidase activity, aminopeptidase activity was inhibited with $1 \mathrm{~m} M 1,10$-phenanthroline. The possibility that $\mathrm{C}$-terminal conversion of vasopressin may have affected the determination of $\mathrm{N}$-terminal conversion can be excluded, because conditions were chosen such that only a few percent of vasopressin was converted C-terminally, and N-terminal fragments of vasopressin can still serve as a substrate for the aminopeptidase.

Prolylendopeptidase activity was reduced by $45-50 \%$ in the frontal and medial temporal cortices of $A D$ patients as compared with tissue from controls matched for age. In contrast, major aminopeptidase activity was not decreased in the frontal and medial temporal cortices of AD patients as compared with control patients. Since major aminopeptidase and prolylendopeptidase are both cytosolic peptidases $[17,18]$, the decrease in the activity 
of the former enzyme is probably not related to neuronal death.

Prolylendopeptidase also appeared to be affected by the age of the AD patients. This can be explained in two possible ways. Firstly, older patients may have died earlier in the disease. This possibility is not supported by the observation that the diagnosed duration of disease was not significantly different between the younger and older $\mathrm{AD}$ patients. Nor was there a correlation between the duration of disease and prolylendopeptidase activity. Secondly, the age dependence of prolylendopeptidase activity may reflect a nosological distinction between late and early onset $\mathrm{AD}$. Rossor et al. [16] have recently reported on the age dependence of neurochemical markers of $\mathrm{AD}$. The present findings corroborate these observations for prolylendopeptidase activity. No effect of age was found on major aminopeptidase activity. The suggestion that an effect on major aminopeptidase activity may have been missed previously [12] can now be excluded.

Prolylendopeptidase activity in the brains of AD patients may be reduced by three possible mechanisms: (1) reduced synthesis of the enzyme; (2) damage to the enzyme; (3) inhibition of the enzyme by an endogenous component or the absence of a cofactor. The latter possibility was excluded by the observation that combination of cytosolic fractions of $\mathrm{AD}$ and control patients did not result in decreases or increases in the sum of activities which would have occurred if an inhibitor or the absence of a cofactor were the cause of the reduced enzyme activity. Nor did heat-denatured cytosolic fractions from AD patients contain an inhibitor of prolylendopeptidase activity.

In striking contrast to our findings Aoyagi et al. [15] found an increase in prolylendopeptidase activity in occipital cortex from $A D$ patients. This cannot be readily explained. It may be related to the particular sample of patients selected by Aoyagi et al. [15] and heterogeneity within $\mathrm{AD}$ cases; these investigators did not diagnose their patients according to the NINCDS-ARDRA criteria [19] and used relatively old patients. In the present study no change was observed in prolylendopeptidase in brain tissue from relatively old AD patients.

$\mathrm{AD}$ is characterized by a disturbance in protein catabolism (deposition of proteins and abnormal protein cleavage) and changes in protein degrading enzymes are probably involved. Whether the disturbance found in the present study is a causative factor in AD and how peptidases participate in the etiology of $A D$ needs further investigation. Prolylendopeptidase is a serine protease and the reduction in prolylendopeptidase activity observed may be representative of other serine proteases.

Some of the enzymes affected in AD are associated with well-defined transmitter systems (e.g., choline acetyltransferase [5]), whereas other enzymes, such as the presently studied peptidases, are of ubiquitous nature. It is likely that these reduced enzyme activities have a common cause. Some enzyme activities may be reduced by dephosphorylation, since tyrosine kinase activity is reduced in $\mathrm{AD}$ [26]. This is not a likely explanation for the changes in the peptidase activities, since the activity of these enzymes is not regulated in such a way. It would be interesting to try to find a common denominator for the changes in enzyme activities observed. Factors that may reduce enzyme activities are changes in cellular metal concentrations [27] and free radical formation [28]. Whether one of these factors is the common denominator is far from certain, but tracing the cause of the changes in enzyme activities may be a fruitful approach to the elucidation of the etiology of AD.

\section{References}

1 Plum F: Dementia; an approaching epidemic. Nature 1979;279:372-373.

2 Adolfsson R, Gottfries CG, Roos BE, Winblad $\mathrm{B}$ : Changes in brain catecholamines in patients with dementia of Alzheimer type. $\mathrm{Br} J$ Psychiatry 1979;135:216-223.

3 Cross AJ, Crow TJ, Perry EK, Perry RH, Blessed G, Tomlinson BE: Reduced dopamine$\beta$-hydroxlase activity in Alzheimer's disease. Br Med J 1981;282:93-94.
4 Davies P: Neurotransmitter-related enzymes in senile dementia of the Alzheimer type. Brain Res 1979;171:319-327.

5 Perry EK, Perry RH: The cholinergic system in Alzheimer's disease; in Roberts PJ (ed): Biochemistry of Dementia. Chichester, Wiley, 1980, pp 135-183.

6 Grundke-Iqual I, Iqbal K, Tung Y-C, Quinlan M, Wisniewski HM, Binder LI: Abnormal phosphorylation in the microtubule-associated $\tau$ (tau) in Alzheimer cytoskeletal pathology. Proc Natl Acad Sci USA 1986;83:4913-4917.
7 Esch FS, Keim PS, Beattie EC, Blacher RW, Culwell AR, Oltersdorf T, McClure D, Ward PJ: Cleavage of amyloid B peptide during constitutive processing of its precursor. Science 1990;1122-1124.

8 Abraham CR, Selkoe DJ, Potter H: Immunochemical identification of the serine protease inhibitor alpha-1-antichymotrypsin in the brain amyloid deposits of Alzheimer's disease. Cell 1988;52:487-501. 
9 Eikelenboom P, Hack CE, Rozemuller JM, Stam FC: Complement activation in amyloid plaques in Alzheimer's dementia. Virchows Arch 1989;56:259-262.

10 Shimohama S, Suenaga T, Araki W, Yamaoaka Y, Shimizu K, Kimuza J: Presence of calpain II immunoreactivity in senile plaques in $\mathrm{Alz}$ heimer's disease. Brain Res 1991;558:105108.

11 Mori H, Kondo J, Ihara Y: Ubiquitin is a component of paired helical filaments in Alzheimer's disease. Science 1987;235:1641-1644.

12 Mantle D, Lauffart B, Perry EK, Perry RH Comparison of major cortical aminopeptidase activity in normal brain and brain from patients with Alzheimer's disease. J Neurol Sci 1989;89:227-234.

13 Kawashima S, Ihara Y, Inomata M: Translgutaminase and calcium-protease activities in Alzheimer's disease brain. Biomed Res 1989 10:17-23.

14 Nilsson E, Alafuzoff I, Blennow K, Blomgren K, Hall CM, Janson I, Karlsson I, Wallin A Gottfries CG, Karlsson J-O: Calpain and calpastatin in normal and Alzheimer-degenerated human brain tissue. Neurobiol Aging 1990;11: $425-431$.
15 Aoyagi $T$, Wada $T$, Nagai $M$, Kojima $F$, Harada $S$, Takeuchi $T$, Takahasi $H$, Hirokawa $K$, Tsumita $\mathrm{T}$ : Deficiency of kallikrein-like enzyme activities in cerebral tissue of patients with Alzheimer's disease. Experientia 1990;46: 94-97.

16 Rossor MN, Iversen LL, Reynolds GP, Mountjoy CQ, Roth M: Neurochemical characteristics of early and late onset types of Alzheimer's disease. Br Med J 1984;288:961-964.

17 McDermott JR, Mantle D, Lauffart B, Kidd AM: Purification and characterization of a neuropeptide-degrading aminopeptidase from human brain. J Neurochem 1985;45:752-759.

18 Yoshimoto T, Simmons WH, Kita T, Tsuru D: Post-proline cleaving enzyme from lamb brain. J Biochem 1981;90:323-334.

19 McKhann G, Drachman D, Folstein M, Katzman $P$, Price D, Stadlan EM: Clinical diagnosis of Alzheimer's disease: Report of the NINCDS-ADRDA work group. Neurology 1984;34:939-944.

20 Reisberg B, Ferris SH, De Leon MJ, Cook T: Alzheimer' disease: A report of progress. Am J Psychol 1982;139:1136-1139.

21 Burbach JPH, Terwel D, Lebouille JLM: Measurement and distribution of vasopressin-converting aminopeptidase-activity in rat brain. Biochem Biophys Res Commun 1987;144: 726-731.
22 Davison JM, Sheills EA, Barron WM, Robinson AG, Lindheimer MD: Changes in the metabolic clearance of vasopressin and in plasma vasopressinase throughout human pregnancy. $\mathrm{J}$ Clin Invest 1989;83:1313-1318.

23 Burbach JPH, Wang X-C, Ten Haaf JA, De Wied D: Substances resembling C-terminal vasopressin fragments are present in the brain but not in the pituitary gland. Brain Res 1984;306: 384-387.

24 Ten Haaf JA, Terwel D, Van de Heijning BJM, Van Wimersma Greidanus TjB: Radioimmunoassay, a goal or a tool? J Control Rel, in press.

25 Burbach JPH, Liu B: Measurement of vasopressin-converting aminopeptidase activity and vasopressin metabolites. Methods Enzymol 1989;168:385-397.

26 Shapiro IP, Masliah E, Saitoh T: Altered protein phosphorylation in Alzheimer's disease. $\mathbf{J}$ Neurochem 1991;56:1154-1162.

27 Wenstrup D, Ehmann WD, Markesbery WR: Trace element imbalancies in isolated subcellular fractions of Alzheimer's disease brains. Brain Res 1990;553:125-131.

28 Subbarao KV, Richardson JS, Ang LC: Autopsy samples of Alzheimer's cortex show increased peroxidation in vitro. $J$ Neurochem 1990;55:342-345. 